Research, Society and Development, v. 9, n. 9, e858998157, 2020

(CC BY 4.0) | ISSN 2525-3409 | DOI: http://dx.doi.org/10.33448/rsd-v9i9.8157

Drying and physiological quality of palheteira seeds (Clitoria fairchildiana R.A. Howard)

Secagem e qualidade fisiológica de sementes de palheteira (Clitoria fairchildiana

\title{
R.A. Howard)
}

EI secado y la calidad fisiológica da las semillas de la palheteira (Clitoria fairchildiana

\section{R.A. Howard)}

Received: 09/03/2020 | Reviewed: 09/06/2020 | Accept: 09/09/2020 | Published: 09/11/2020

\section{Érica Coutinho David}

ORCID: https://orcid.org/0000-0001-9388-1027

Universidade Federal Rural da Amazônia, Brasil

E-mail: ericacdavid3@gmail.com

Bressa Karolina Dias Cardoso

ORCID: https://orcid.org/0000-0002-3705-9474

Universidade Federal Rural da Amazônia, Brasil

E-mail: bressa.12@gmail.com

Josiene Amanda dos Santos Viana

ORCID: https://orcid.org/0000-0002-7602-5832

Universidade Federal Rural da Amazônia, Brasil

E-mail: josieneamanda@gmail.com

Eniel David Cruz

ORCID: https://orcid.org/0000-0001-6003-3152

Embrapa Amazônia Oriental, Brasil

E-mail: eniel.cruz@embrapa.br

\begin{abstract}
Knowledge about seed storage behavior is important to preserve plant species. Clitoria fairchildiana R.A.Howard is an endemic species with medicinal properties, it is used in the recovery of degraded land. The objective of this study is to evaluate the effect of drying on the physiological quality of $C$. fairchildiana seeds. Seeds were oven dried along with silica gel for 18 days and in intervals of 2 or 3 days, samples were removed to assess the seed moisture content. This was done in an oven at $105 \pm 3{ }^{\circ} \mathrm{C}$ for $24 \mathrm{~h}$, using four replicates with 10 seeds each. After undergoing the above-mentioned treatment, a sample of seeds was stored in the freezer $\left(-18{ }^{\circ} \mathrm{C}\right)$ for 3 months. Sowing was carried out in plastic trays in a sand and
\end{abstract}


sawdust mixture $(1: 1)$, previously sterilized in hot water $\left(100{ }^{\circ} \mathrm{C}\right)$ for two hours. Seeds were left to germinate in a laboratory with no temperature and relative humidity control. Germination tests were performed over 14 days with daily counts of the number of emerged seedlings. The percentage of seed germination, abnormal seedlings and dead seeds were obtained 14 days after sowing. The experimental design was completely randomized with four replications of 25 seeds. The reduction of seed moisture content from $18.5 \%$ to $5.6 \%$ affected physiological seed quality causing a reduction in the germination percentage and an increase in dead seeds and abnormal seedling percentage. $C$. fairchildiana seeds are classified as intermediate and they can be desiccated up to $8.6 \%$ with no reduction in physiology quality.

Keywords: Desiccation; Storage; Vigor; Seed moisture content.

\section{Resumo}

O conhecimento acerca o armazenamento de sementes é importante para a preservação de espécies vegetais. A Clitoria fairchildiana R.A.Howard é uma espécie endêmica com propriedades medicinais utilizada na reconstituição de áreas degradadas. O objetivo deste estudo foi analisar o efeito da secagem na qualidade fisiológica de sementes dessa espécie. As sementes foram secadas em sílica gel por 18 dias em intervalos de 2 ou 3 dias amostras foram retiradas para determinação do grau de umidade. Este foi obtido em estufa a $105 \pm 3^{\circ} \mathrm{C}$ por $24 \mathrm{~h}$, com 4 repetições de 10 sementes. Após obter o último grau de umidade uma amostra das sementes foi armazenada em freezer $\left(-18^{\circ} \mathrm{C}\right)$ por 90 dias. A semeadura foi em vasos contendo substrato de areia e serragem, na proporção de 1:1, previamente cozido em água aquecida por duas horas. Os vasos permaneceram em laboratório desprovido de controles de temperatura e de umidade relativa do ar. O teste de germinação ocorreu durante 14 dias com contagem diária das plântulas emersas e no final desse determinou-se as porcentagens de germinação, sementes mortas e plântulas anormais. O delineamento foi inteiramente casualizado com quatro repetições de 25 sementes por tratamento. A redução do grau de umidade de 18,5\% para 5,6\% afetou a qualidade fisiológica das sementes acarretando redução na taxa de germinação e aumento na porcentagem de sementes mortas e de plântulas anormais. Sementes de C. fairchildiana são classificadas como intermediária no armazenamento e podem ser secadas até $8,6 \%$ sem alteração na qualidade fisiológica.

Palavras-chave: Dessecamento; Armazenamento; Vigor; Grau de umidade da semente. 


\section{Resumen}

El conocimiento sobre el almacenamiento de semillas es importante para la preservación de especies vegetales. La Clitoria fairchildiana R.A.Howard es una especie endémica con propriedades medicinales utilizada en la reconstitución de áreas degradadas. El objetivo de este estudio fue analizar el efecto del secado en la calidad fisiológica de las semillas de esta especie. Las semillas se secaron en gel de sílice durante 18 días y, en intervalos de 2 o 3 días, se fueron retirando muestras para determinar el grado de humedad. Este se obtuvo en invernadero a $105 \pm 3{ }^{\circ} \mathrm{C}$ durante $24 \mathrm{~h}$, con 4 repeticiones de 10 semillas. Después de obtener el último grado de humedad, se almacenó una muestra de las semillas en frigorífico $\left(-18^{\circ} \mathrm{C}\right)$ durante 90 días. La siembra se hizo en macetas que contenían substrato de arena y serrín, en la proporción de 1:1, previamente hervido en agua durante dos horas. Las macetas permanecieron en laboratorio desprovisto de controles de temperatura y de humedad relativa del aire. La prueba de germinación se desarrolló durante 14 días con cuenta diaria de las plántulas emergidas y, a finales de esta, se determinaron los porcentajes de germinación, las semillas muertas y las plántulas anormales. El delineamento fue completamente casualizado con cuatro repeticiones de 25 semillas por tratamiento. La reducción del grado de humedad del 18,5\% a 5,6\% afectó a la calidad fisiológica de las semillas acarreando una reducción en la tasa de germinación y un aumento en el porcentaje de semillas muertas y de plántulas anormales. Las semillas de C. fairchildiana se clasifican como intermedias en el almacenamiento y pueden secarse hasta un 8,6\% sin alteración en la calidad fisiológica.

Palabras clave: Desecación; Almacenamiento; Vigor; Grado de humedad de la semilla.

\section{Introduction}

One important way to preserve plant species is through seed storage. Consequently, knowledge of seed storage behavior is important in order to determine whether or not seed storage is suitable (Hong et al., 1998). Seed longevity is influenced by the plant species and environmental conditions (Sano et al., 2015), as well as temperature and moisture content during storage (Smaniotto et al., 2014).

Roberts (1973) classified seed storage behavior as orthodox and recalcitrant. Orthodox seeds can be dried up to $2 \%$ to $5 \%$ and stored at low temperatures without affecting germination, while recalcitrant seeds should be stored with high seed moisture content, between $12 \%$ to $31 \%$, depending on the species (Roberts, 1973), and they cannot be stored during a long period without reducing viability (Kleinwächter et al., 2014). 
Subsequently a third category intermediate between the orthodox and recalcitrant was identified (Ellis et al., 1990). The physiological quality of intermediate seeds can be affected when seed moisture content is low, between $7 \%$ to $12 \%$, depending on the species (Hong and Ellis, 1996), and they do not tolerate low temperatures (Ellis et al., 1990). Therefore, information about seed storage behavior is essential to the conservation of plant species for a short- or long-term period.

Clitoria fairchildiana R.A.Howard, commonly known in Brazil as palheteira, is an endemic species from Brazil found naturally in the states of Amapá and Pará (Fantz, 1990) and it has spread to all states of Brazil, except Acre, Mato Grosso, Roraima and the Distrito Federal (Flora do Brasil, 2020). It occurs in areas of anthropic vegetation, cerrado, restinga and riparian forest (BFG, 2015; Rando \& Souza, 2015).

According to Lorenzi (2009), this is a fast-growing species used in landscaping, civil construction, rural and urban afforestation and recovery of degraded areas. In the medicinal scope, it presents anti-tumor proprieties induced by rotenoids and lectins (Santos, 2014); this same biochemical property has insecticidal potential (Dantzger, 2015), being a promising alternative among the native species that can be used in the pharmaceutical industry.

The objective of this study is to study the effect of desiccation on the physiological quality of $C$. fairchildiana seeds.

\section{Materials and Methods}

The fruits were harvested from three trees at the Universidade Federal do Pará, in Belém, State of Pará, Brazil $\left(01^{\circ} 28^{\prime} \mathrm{S} ; 48^{\circ} 27^{\prime} \mathrm{W}\right)$ and the experiment was carried out at Embrapa Amazônia Oriental, in Belém, State of Pará, Brazil.

The experiment was carried out for four months, in laboratory conditions, without control of temperature and relative humidity. The experiment was carried out in a completely randomized design with 10 treatments and 4 replications of 25 seeds for each treatment.

The seeds were manually removed from the fruits and after that, the seeds damaged by insects were eliminated. The seeds were dried in an oven containing silica gel in the proportion of $1.250 \mathrm{~g}$ of silica to 1,700 seeds. Samples were taken every 3 days and seed moisture content was determined in four replications of 10 seeds, in an oven set at $105 \pm 3^{\circ} \mathrm{C}$ for $24 \mathrm{~h}$ (Brasil, 2009). Moisture content percentage was expressed on a fresh weight basis (fwb). After obtaining the last treatment $\left(18^{\text {th }}\right.$ day), a sample of 150 seeds were stored in a freezer $\left(-18^{\circ} \mathrm{C}\right)$ for 90 days according to Hong and Ellis (1996). 
The sowing was on a horizontal position at a depth $1.0 \mathrm{~cm}$ in pots $(23 \mathrm{~cm} \times 18 \mathrm{~cm})$, in the substrate containing $5 \mathrm{~kg}$ (dry weight) of substrate. The substrate used was a mixture of sand and sawdust $(1: 1)$, previously cooked in hot water $\left(100{ }^{\circ} \mathrm{C}\right)$ for two hours to reduce microbial contaminants. Seeds were left to germinate in a laboratory under no temperature control and relative humidity (minimum and maximum temperature and relative humidity were $22^{\circ} \mathrm{C}$ and $29^{\circ} \mathrm{C}$, and $74 \%$ and $95 \%$, respectively).

The emergence test was carried out for 14 days with a daily counting of emerged seedling. A seedling was considered emerged when it showed the cotyledon above the substrate surface. At the end of emergence test, the substrate was washed and the germination percentages (normal seedlings), dead seeds and abnormal seedlings were determined according to the Rules for Seeds Analysis (Brasil, 2009). The seedling emergence index was calculated by counting the number of emerged seedlings quantified during the emergence test (Maguire, 1962).

The days to germination emergence onset were quantified by the number of days from sowing until germination of the first seed. At the end of emergence test, the seedlings were removed from substrate and divided into root, stem, and leaf, and then packaged in a paper bag and dried at $68{ }^{\circ} \mathrm{C}$ in an oven with forced air for $48 \mathrm{~h}$. Finally, the samples were weighed to determine the dry mass of the roots, stems, and leaves.

This methodology was described by Hong and Ellis (1996) and it is used in tropical species as Manilkara huberi (Ducke) A. Chev (Barros et al., 2019) and Theobroma grandiflorum (Willd. ex Spreng.) K. Schum. (Cruz \& Cicero, 2008) to classified seeds according to tolerance, to desiccation and storage behavior.

The experimental design was completely randomized with four replications of 25 seeds for each moisture content. Data were subjected to Levene test for homogeneity of variance (Zar, 1996). The variables stem dry mass and root dry mass were transformed using $\log (x+1)$. Data were subjected to analysis of variance and means compared by Tukey's test $(\mathrm{p} \leq 0.05)$ using Statistica software (Statsoft, 2016) to perform all analyses. Data were back transformed for presentation.

\section{Results and Discussion}

In Figure 1 was observed equations not linear of the drying and seed germination of palheteira. The initial moisture content of palheteira seeds was higher than that reported by Cruz and Pereira (2019). 
Figure 1. Drying $\left(\mathrm{y}=29.131\left(1+\exp \left(-(\mathrm{x}-7.169) /-4.231 ; \quad \mathrm{R}^{2}=0.98\right) \quad\right.\right.$ and germination $\left.\mathrm{y}=92.109(1+\exp (-(\mathrm{x}-5.624) /-1.167)) ; \mathrm{R}^{2}=0.98\right)$ curve palheteira (Clitoria fairchildiana) seeds.

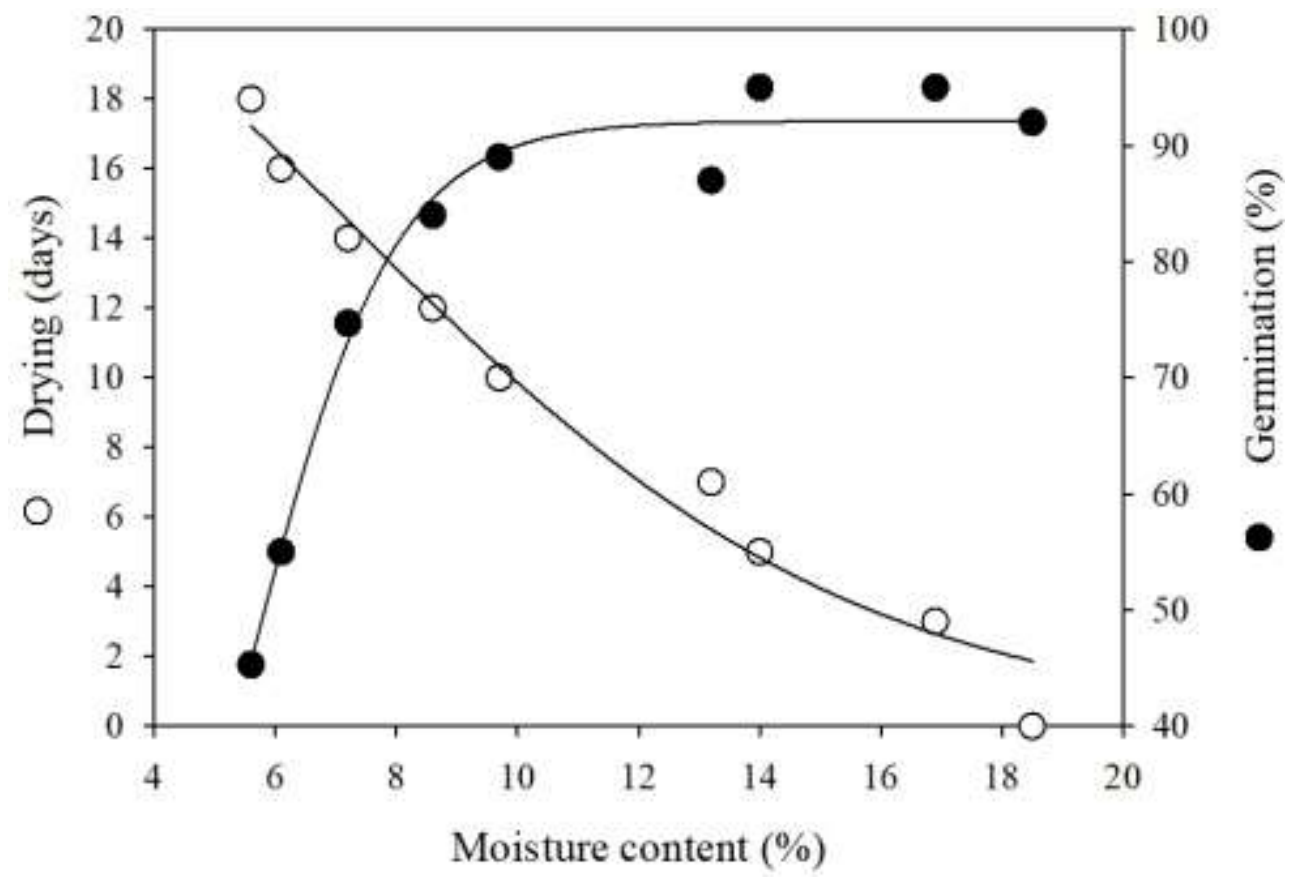

Source: Authors.

In Table 1 was observed the effect of moisture content reduction in physiological quality of seeds. Statistically significant differences $(P \leq 0.05)$ between treatments were observed for all the variables. Reduction of the seed moisture content to $8.6 \%$ did not affect emergence, emergence speed index, germination, dead seed and abnormal seedlings. 
Table 1. Desiccation time (DT), seed moisture content (U), days to germination emergence onset (DGO), emergence (E), emergence speed index (ESI), germination (G), dead seeds (DS) and abnormal seedling (AS) in C. fairchildiana seeds during drying.

\begin{tabular}{cccccccc}
\hline $\begin{array}{c}\text { DT } \\
(\text { days })\end{array}$ & $\begin{array}{c}\text { U } \\
(\%)\end{array}$ & DGO & $\begin{array}{c}\text { E } \\
(\%)\end{array}$ & ESI & G & $\begin{array}{c}\text { DS } \\
(\%)\end{array}$ & AS \\
\hline 0 & 18.5 & $6.0 \mathrm{~b}$ & $93.0 \mathrm{a}$ & $3.31 \mathrm{a}$ & $92.0 \mathrm{ab}$ & $4.0 \mathrm{ab}$ & $4.0 \mathrm{a}$ \\
3 & 16.9 & $6.3 \mathrm{~b}$ & $96.0 \mathrm{a}$ & $3.21 \mathrm{a}$ & $95.0 \mathrm{a}$ & $2.0 \mathrm{a}$ & $3.0 \mathrm{a}$ \\
5 & 14.0 & $6.8 \mathrm{bc}$ & $97.0 \mathrm{a}$ & $3.25 \mathrm{a}$ & $95.0 \mathrm{a}$ & $3.0 \mathrm{ab}$ & $2.0 \mathrm{a}$ \\
7 & 13.2 & $6.0 \mathrm{~b}$ & $90.0 \mathrm{a}$ & $3.12 \mathrm{a}$ & $87.0 \mathrm{ab}$ & $9.0 \mathrm{ab}$ & $4.0 \mathrm{a}$ \\
10 & 9.7 & $6.0 \mathrm{~b}$ & $93.0 \mathrm{a}$ & $3.09 \mathrm{ab}$ & $89.0 \mathrm{ab}$ & $6.0 \mathrm{ab}$ & $5.0 \mathrm{a}$ \\
12 & 8.6 & $6.8 \mathrm{bc}$ & $90.0 \mathrm{a}$ & $2.93 \mathrm{ab}$ & $84.0 \mathrm{ab}$ & $9.0 \mathrm{ab}$ & $7.0 \mathrm{ab}$ \\
14 & 7.2 & $7.0 \mathrm{c}$ & $84.0 \mathrm{ab}$ & $2.57 \mathrm{bc}$ & $74.7 \mathrm{~b}$ & $10.6 \mathrm{ab}$ & $14.7 \mathrm{ab}$ \\
16 & 6.1 & $6.8 \mathrm{bc}$ & $70.0 \mathrm{~b}$ & $2.12 \mathrm{c}$ & $55.0 \mathrm{c}$ & $17.0 \mathrm{~b}$ & $28.0 \mathrm{~b}$ \\
18 & 5.6 & $5.0 \mathrm{a}$ & $50.7 \mathrm{c}$ & $1.45 \mathrm{~d}$ & $45.3 \mathrm{c}$ & $45.4 \mathrm{c}$ & $9.3 \mathrm{ab}$ \\
$\mathrm{SS}$ & 5.9 & $8.0 \mathrm{~d}$ & $47.0 \mathrm{c}$ & $1.36 \mathrm{~d}$ & $42.0 \mathrm{c}$ & $42.0 \mathrm{c}$ & $16.0 \mathrm{ab}$ \\
\hline
\end{tabular}

Differences in means followed by the same letter are not statistically significant by Tukey test $(P \geq$ 0.05). Source: Authors.

According to Hong and Ellis (1992), seeds show reduced viability when their content reaches a critical level. For palheteira seeds, the critical level of moisture content was $7.2 \%$ with a decrease in the germination percentage. The decrease in water content resulted in a decreased physiological quality of the seeds, considering an increase in the number of dead seeds and abnormal seedlings (Table 1).

The dry mass of root, stem, leaf, and total are showed in Table 2. Reduction the moisture content decreased the dry mass production in different components of seedlings, with higher regarding the seedling dry mass, the reduction was more accentuated from $9.7 \%$. 
Table 2. Moisture content (U), leaf dry mass (LDM), stem dry mass (SDM), root dry mass (RDM) and total dry mass (TDM) in C. fairchildiana seeds during drying.

\begin{tabular}{ccccc}
\hline $\begin{array}{c}\mathrm{U} \\
(\%)\end{array}$ & LDM & $\begin{array}{c}\text { SDM } \\
(\mathrm{mg} / \mathrm{seedling})\end{array}$ & $\begin{array}{c}\text { RDM } \\
18.5\end{array}$ & \multicolumn{3}{c}{$\begin{array}{c}\text { TDM } \\
18.7 \mathrm{a}\end{array}$} & $98.7 \mathrm{ab}$ & $63.2 \mathrm{a}$ & $200.5 \mathrm{a}$ \\
16.9 & $24.4 \mathrm{bc}$ & $103.0 \mathrm{a}$ & $42.7 \mathrm{bc}$ & $170.1 \mathrm{bc}$ \\
14.0 & $32.7 \mathrm{ab}$ & $92.9 \mathrm{ab}$ & $50.4 \mathrm{ab}$ & $176.0 \mathrm{ab}$ \\
13.2 & $42.9 \mathrm{a}$ & $85.9 \mathrm{bc}$ & $41.6 \mathrm{bc}$ & $170.4 \mathrm{bc}$ \\
9.7 & $17.6 \mathrm{~cd}$ & $72.4 \mathrm{~cd}$ & $31.0 \mathrm{cde}$ & $121.0 \mathrm{~d}$ \\
8.6 & $14.2 \mathrm{~d}$ & $67.6 \mathrm{~d}$ & $28.6 \mathrm{cde}$ & $110.4 \mathrm{~d}$ \\
7.2 & $19.4 \mathrm{~cd}$ & $83.2 \mathrm{bcd}$ & $35.8 \mathrm{bcd}$ & $138.4 \mathrm{~cd}$ \\
6.1 & $6.7 \mathrm{e}$ & $46.7 \mathrm{e}$ & $18.9 \mathrm{de}$ & $72.3 \mathrm{e}$ \\
5.6 & $7.7 \mathrm{e}$ & $36.6 \mathrm{ef}$ & $12.9 \mathrm{e}$ & $57.1 \mathrm{e}$ \\
5.9 & $4.5 \mathrm{e}$ & $27.6 \mathrm{f}$ & $23.5 \mathrm{de}$ & $55.7 \mathrm{e}$ \\
\hline
\end{tabular}

Differences in means followed by the same letter are not statistically significant by Tukey $(\mathrm{p}<0.05)$. Source: Authors.

When seeds were frozen at $-18^{\circ} \mathrm{C}$ for 90 days it was observed statistically that freezing did not modify the emergence, emergence speed index, germination, dead seeds and abnormal seedlings, showing that the seed physiological quality is affected by the reduced water content, not the freezing.

Alves et al. (2015) and Pelissari et al. (2018) studying seed desiccation classified palheteira seeds as orthodox, diverging from the present study that classified palheteira seeds as intermediate in storage. Alves et al. (2015) dried palheteira seeds around $8 \%$ and $78 \%$ of germination, but according to Hong and Ellis (1996), this water content is a characteristic of intermediate species, and orthodox species have a desiccation of at least $2 \%$ to $6 \%$ moisture content depending on the species.

Mayrinck et al. (2016) studying seeds from native species from Brazil observed 59.1\% were classified as intermediate species according to the Hong and Ellis protocol (1996). Baskin and Baskin (2004) and Kleinwächter et al. (2014) explained that the majority of tropical seeds are classified as recalcitrant or intermediate due to the favorable climatic conditions in tropical rainforests; that is, seeds of most tropical plants germinate as soon as fruits are mature, so there is no need to develop outlasting mechanisms.

In other tropical species, whose seeds are classified as intermediate in storage, Genipa 
americana L., the maintenance of the physiological seed quality is possible when seed moisture content is reduced to $10 \%$, close to the value obtained for palheteira seeds (Magistrali et al., 2013).

\section{Conclusions}

Clitoria fairchildiana seeds exhibit intermediate characteristics in storage, and it possible to maintain seed quality with seed moisture content equal to or higher than $8.6 \%$. In the next phase of this research, it will be evaluated the effect of temperature and storage time on the physiological quality of seeds.

\section{References}

Alves, M. M., Alves, E. U., \& Santos-Moura, S. S. (2015). Physiological quality seeds of Clitoria fairchildiana R.A.Howard during storage. Bioscience Journal, 31 (3), 767-774, 2015. DOI: https://doi.org/10.14393/BJ-v31n3a2015-26085

Barros, H. S. D., Cruz, E. D., \& Pereira, A. G. (2019). Classificação fisiológica de sementes de maçaranduba quanto a tolerância à dessecação e ao armazenamento. Revista de Ciências Agrárias, 62. DOI: http://dx.doi.org/10.22491/rca.2019.2949

Baskin, J. M., \& Baskin, C.C. (2004) A Classification System for Seed Dormancy. Seed Science Research, 14, 1-16. DOI: http://dx.doi.org/10.1079/SSR2003150

Brasil. Ministério da Agricultura, Pecuária e Abastecimento. (2009). Regras para Análise de Sementes. Brasília: Mapa/ACS.

BFG. (2015). Growing knowledge: an overview of seed plant diversity in Brazil. Rodriguésia, 66 (4), 1085-1113. DOI: 10.1590/2175-7860201566411

Costa, M.C.D., Cooper, K., Hilhorst, H.W.M., \& Farrant, J.M. (2017) Orthodox Seeds and Resurrection Plants: Two of a Kind? Plant Physiology, 175, 589-599. DOI: https://doi.org/10.1104/pp.17.00760 
Cruz, E. D., \& Pereira, A. G. (2019). Germinação de sementes de espécies amazônicas: palheteira (Clitoria fairchildiana R.A.Howard). Belém, PA: Embrapa Amazônia Oriental. (Technical Bulletin, 314).

Cruz, E. D. \& Cicero, S. M. (2008). Sensitivity of seed to desiccation in cupuassu (Theobroma grandiflorum (Willd. ex Spreng.) K. Schum. - Sterculiaceae. Scientia Agricola, 65 (5), 557-560. DOI: https://doi.org/10.1590/S0103-90162008000500017

Dantzger, M., Vasconcelos, I. M., Scorsato, V., Aparicio, R., Marangoni, S., \& Macedo, M. L. R. (2015). Bowman-Birk proteinase inhibitor from Clitoria fairchildiana seeds: Isolation, biochemical properties and insecticidal potential. Phytochemistry, 118, 224-235. DOI: https://doi.org/10.1016/j.phytochem.2015.08.013

Ellis, R. H., Hong, T. D., \& Roberts, H. (1990). An intermediate category of seed storage behaviour? I. Coffee. Journal of Experimental of Botany, 41 (230), 1167-1174. DOI: https://doi.org/10.1093/jxb/41.9.1167

Fantz, P. R. (1990). Clitoria (Leguminosae) antillarum. Moscosoa, 6, 152-166.

Flora do Brasil 2020 em construção. (2020). Clitoria. Retrived from http://floradobrasil.jbrj.gov.br/reflora/floradobrasil/FB29540.

Hong, T. D. \& Ellis, R. H. (1996). A protocol to determine seed storage behavior. Rome: International Plant Genetic Resources Institute. (Technical Bulletin, 1).

Hong, T. D., Linington, S., \& Ellis, R. H. (1998). Compendium of information on seed storage behavior. Kew: Basingstore Press.

Kleinwächter, M., Radwan, A., Hara, M., \& Selmar, D. (2014). Dehydrin expression in seeds: an issue of maturation drying. Frontiers in Plant Science, 5 (402). DOI: https://doi.org/10.3389/fpls.2014.00402

Lorenzi, H. (2009) Árvores brasileiras: manual de identificação de e cultivo de plantas arbóreas nativas do Brasil. (3 ed). Nova Odessa: Instituto Plantarum. 
Magistrali, P. R., José, A. C., Faria, J. M. R., \& Gasparin, E. (2013). Physiological behavior of Genipa americana L. seeds regarding the capacity for desiccation and storage tolerance. Journal of Seed Science, 35 (4), 495-500. DOI: https://doi.org/10.1590/S231715372013000400011

Maguire, J. D. (1962). Speed of germination-aid in relation evaluation for seedling emergence vigor. Crop Science, 2 (2), 176-177.

Mayrinck, R. C., Vaz, T. A. A., \& Davide, A. C. (2016) Classificação fisiológica de sementes florestais quanto à tolerância à dessecação e ao comportamento no armazenamento. Cerne, 22 (1), 85-92. DOI: https://doi.org/10.1590/01047760201622012064.

Pelissari, F., José, A. C., Fontes, M. A. L., Matos, A. C. B., Pereira, W. V. S., \& Faria, J. M. R. (2018). A probabilistic model for tropical tree seed desiccation tolerance and storage classification. New Forests, 49, 143-158. DOI: https://doi.org/10.1007/s11056-017-9610-8

Rando, J. G., \& Souza, V.C. (2015). Clitoria in Lista de Espécies da Flora do Brasil. Retrived from http://floradobrasil.jbrj.gov.br/jabot/floradobrasil/FB29540

Roberts, E. H. (1973). Predicting the storage life of seeds. Seed Science and Seed Technology, $1(3), 499-514$.

Sano, N.; Rajjou, L., North, H. M., Debeaujon, I., Marion-Poll, A., \& Seo, M. (2016). Staying Alive: Molecular Aspects of Seed Longevity. Plant \& Cell Physiology, 57 (4), 660-674. DOI: $10.1093 / \mathrm{pcp} / \mathrm{pcv} 186$

Santos, R. A. F. (2014). Estudo fitoquímico e avaliação biológica dos flavonoides isolados de Clitoria fairchildiana $R$. A. Howard. (Unpublished doctoral thesis). Universidade Federal da Bahia/UFBA, Salvador.

Smaniotto, T. A. S., Resende, O., Marçal, K. A. F., Oliveira, D. E. C., \& Simon, G. A. (2014). Qualidade fisiológica das sementes de soja armazenadas em diferentes condições. Revista 
Brasileira de Engenharia Agrícola e Ambiental, 18 (4), 446-453. DOI: https://doi.org/10.1590/S1415-43662014000400013

Statsoft. (2016). Statistica for windows. (13th ed). Tulsa: StatSoft. (General conventions and statistics).

Zar, J. H. (1996). Biostatistical analysis. Upper Saddle River: Prentice Hall.

Percentage of contribution of each author in the manuscript

Érica Coutinho David - 40\%

Bressa Karolina Dias Cardoso - 20\%

Josiene Amanda dos Santos Viana - 20\%

Eniel David Cruz - 20\% 